\title{
Impact of elevated carbon dioxide and temperature on wheat production under sub temperate climate in north western Himalayas, India
}

\author{
Ranbir Singh Rana ${ }^{1 *}$, Ranu Pathania ${ }^{2}$, Ramesh $^{3}$, Sanjay Kumar Sharma ${ }^{4}$ and Shivani \\ Thakur ${ }^{5}$ \\ ${ }^{1 \& 2}$ Centre for Geo- Informatics Research and Training, Chaudhary Sarwan Kumar Himachal Pradesh Krishi \\ Vishvavidyalaya, Palampur-176062 (HP), INDIA \\ ${ }^{3}$ Presently at Abhilashi University, Mandi (HP), INDIA \\ ${ }^{4}$ Krishi Vigyan Kendra, Kangra, CSK Himachal Pradesh Krishi Vishvavidyalaya, Palampur-176062 (HP), INDIA \\ ${ }^{5}$ Department of Agronomy, CSK Himachal Pradesh Krishi Vishvavidyalaya, Palampur-176062 (HP), INDIA \\ *Corresponding author. E-mail: ranars66@gmail.com
}

Received: October 22, 2016; Revised received: April 7, 2017; Accepted: September 5, 2017

Abstract: Wheat is the second most important cereal crop and plays a key role in food and nutritional security. The study examines the impact of elevated carbon dioxide and temperature under limited irrigations on wheat crop using crop growth simulation models under sub temperate climate. The InfoCrop model was validated using the historical data generated by the research trials of All India Coordinated Research Improvement Project at Palampur, Himachal Pradesh. The model was run for 20 years from 1991 to 2010 for Palampur weather station. The results revealed 3.6

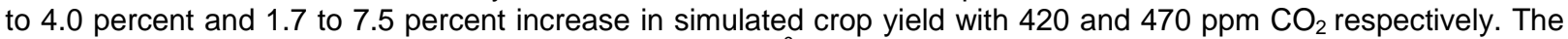
elevated maximum and minimum temperature by 1 and $2^{\circ} \mathrm{C}$ with $370 \mathrm{ppm}$ carbon dioxide reduced the anthesis period by 5-7 and 9-11 days respectively over the sowing window of November $15^{\text {th }}$ to December $30^{\text {th }}$. Similarly, days to maturity also reduced by $4-5$ and 7-8 days with 1 and $2^{\circ} \mathrm{C}$ rise in temperature respectively. The simulated crop yield showed increase by 17.9 to 63.0 and 33.2 to 133.4 percent with 1 and $2^{\circ} \mathrm{C}$ rise in temperature at $370 \mathrm{ppm}^{\mathrm{CO}}$ under limited irrigations. The simulated grain yield at $420 \mathrm{ppm} \mathrm{CO}_{2}$ showed an increase of 23 to 69.7 percent with $1^{\circ} \mathrm{C}$ and 39.5 to 123.5 percent with $2^{\circ} \mathrm{C}$ whereas at $470 \mathrm{ppm} \mathrm{CO}_{2}$ level the increase was 27.9 to 76.1 at $1^{\circ} \mathrm{C}$ and 46.4 to 133.0 percent with $2^{\circ} \mathrm{C}$ rise in maximum and minimum temperatures respectively. Hence, simulated results of elevated temperature and $\mathrm{CO}_{2}$ levels proved to be beneficial in rabi wheat with adaptations strategy of limited irrigations under sub temperate climate of North Western Himalayas

Keywords: Assessment, Adaptation, Elevated $\mathrm{CO}_{2}$, InfoCrop, Simulation, Temperatures, Wheat

\section{INTRODUCTION}

Wheat \{Triticum aestivum (L.) emend. Fiori \& Paol. $\}$ is the staple food of millions of Indians, particularly in the northern of the country. In India, wheat is produced in 31.19 million ha area with 94.49 million tonne of production and $3.03 \mathrm{t} / \mathrm{ha}$ productivity (Annonymous, 2015). It is grown from temperate irrigated to dry and high rainfall area, and from warm humid to dry cold environment. Climate change and variability have the potential to significantly affect the production of wheat. In Himachal Pradesh, this crop is presently being cultivated on 341 thousand ha with a production of 680 thousand tonne and productivity of 1.9 t/ha--(Annonymous, 2014). Future climate scenarios may be beneficial for wheat in some regions (Richter and Semenov, 2005), but could reduce productivity in zones where optimal temperatures already exist (Ortiz et al., 2008). In mountain state of Himachal Pradesh, evidences of global warming are clearly demonstrated by receding rainfall and increasing temperature, ad- versely affecting the crop productivity (Bhagat et al., 2007). In the face of climate change impact on crops, optimum sowing time is one of the adaptation measures to cope with climatic variability. Shift in sowing dates have a great bearing on phasic development and dry matter partitioning of crop as variation in climate and growing degree days modifies varietal performance. The main constraint in assessing risk from climate change is the lack of long-term weather data. Agricultural productivity is sensitive to climate change due to direct effects of changes in temperature, precipitation and carbon dioxide concentrations, and also due to indirect effects through changes in soil moisture and the distribution and frequency of infestation by pests and diseases (Mendelsohn, 2014). The spectre of depleting water availability through receding Himalayan reservoirs and diminishing natural recharge can prove to be a kingpin in reduction of wheat productivity. The evolving judicious water management strategies in crops can adapt the plausible impacts of changing climate. Kumar et al. (2014) reported 6 to 23 and 15 to 
$25 \%$ reduction in the wheat yield in India during 2050s and 2080s, respectively, under projected climate change scenarios. The study presents the impact of projected climate change (temperature and $\mathrm{CO}_{2}$ ) on performance of wheat under sub-humid and subtemperate climatic conditions of Himachal Pradesh using InfoCrop, a crop simulation model developed by Aggarwal et al, (2006a) considering the coefficients worked under Indian conditions.

\section{MATERIALS AND METHODS}

Site description: The experimental site is represented by the sub temperate climate during the rabi crop season having mean maximum and minimum temperature between $4.9^{\circ} \mathrm{C}$ (February) to $31^{\circ} \mathrm{C}$ (May) . The regional fall under mid hill region (1290 m amsl.) with mean rainfall during crop season is $450 \mathrm{~mm}$. Increasing trend was observed throughout the year in the mean temperature change except June (less than $-0.5^{\circ} \mathrm{C}$ ). The maximum value was during March and December (more than $2^{\circ} \mathrm{C}$ ). In the irrigated area generally 3-4 irrigation are available. The simulation was tried with pre-sown irrigation and three irrigations at 40, 80 and 120 days after each sowing window.

Model description: InfoCrop is a generic crop model designed to simulate the effects of weather, soils, agronomic management (including planting, nitrogen, residues and irrigation), and major pests on crop yield and its associated environmental impacts. Each process is described by a set of equations, in which the parameters vary depending upon the crop/ cultivar. InfoCrop considers the processes such as crop growth and development (phenology, photosynthesis, partitioning, leaf area growth, storage organ numbers, source: sink balance, transpiration, uptake, allocation and redistribution of nitrogen), effects of water, nitrogen, temperature, flooding and frost stresses on crop growth and development, crop-pest interactions (damage mechanisms of insects and diseases), soil water balance, soil nitrogen balance, soil organic carbon dynamics, emissions of green house gases and climate change module. More details of the model are provided by Aggarwal et al. (2006a).

Model input requirements: The InfoCrop growth model requires input data on crop/variety master, soil texture master and weather for successful execution

Crop/variety file: The crop variety details like variety name, crop phenology (days to anthesis, days to maturity etc.), leaf area index, grain yield above ground biomass, 1000 grain weight are required to develop genotypic coefficients and characterize the basic physiological behavior of a variety.

Weather:. Daliy weather parameters viz. maximum and minimum temperature, rainfall, relative humidity, solar radiations are essential and wind speed and vapour pressure are optional parameters required to execute the crop model. The physiography of the study site (latitude, longitude and altitude) and crop season inputs are also required .

Soil texture: Soil thickness upto three layers, $\mathrm{pH}, \mathrm{EC}$, $\mathrm{N}, \mathrm{P}, \mathrm{K}$, soil organic carbon, soil texture, sand and clay percent, soil moisture, saturation, saturated hydraulic conductivity, field capacity wilting point of soil, and bulk density.

Crop management: Seed rate, specific leaf area of variety, grain weight of crop, date of sowing are required to initiate the simulation process. The agronomic operations namely irrigation, fertilizer manure; crop residue etc. with amount ,type,time of application and depth of placement are required to execute the model.

Output variables: The standard outputs comprises crop developmental stage,daily drymatter of stem, leaves and roots, grain number and grain yield, leaf area index, $\mathrm{N}$ uptake by crop, soil water and $\mathrm{N}$ content, evapotranspiration, $\mathrm{N}$ and water stress , flooding, methane and $\mathrm{CO}_{2}$ emission etc.

Calibration and validation of model: In order to calibrate and validate the crop simulation model for different phenophases ( Days to reproductive phase $\&$ maturity) and grain and straw yield of wheat, the observed field data were taken from All India Coordinated Wheat Research Improvement Project at Palampur for three dates of sowings i.e. $30^{\text {th }}$ November, $15^{\text {th }}$ and $30^{\text {th }}$ December (Rabi 2000-2001 and 2001-2002). The phenological data of variety HS-295 was taken for validation of the model. To evaluate model performance, statistical indicator of root mean square error (RMSE) was computed from observed and simulated variables (Days to maturity: 12.5 days and grain yield of wheat : $426.8 \mathrm{~kg}$ ). The lower difference between observed and simulated values of crop parameters indicated the good fitness of model.

Impact assessment of climate change: The study area was represented by sub-humid and sub-temperate climate with $450 \mathrm{~mm}$ mean rainfall is received durng rabi season. The seasonal climate scenarios of $1^{\circ} \mathrm{C}$ and $2^{\circ} \mathrm{C}$ rise in maximum and minimum temperature and elevated carbon dioxide levels $\left(\mathrm{CO}_{2}\right)$ of 50 and $100 \mathrm{ppm}$ from normal of $370 \mathrm{ppm}$ were used in the model to assess the impact of weather parameters variability. The model was executed for 20 years using data from 1991 to 2010 for Palampur weather station.

\section{RESULTS AND DISCUSSION}

Validation of model: The InfoCrop model simulated and observed days to anthesis for wheat crop under late sown conditions were compared for different planting dates (Figs. 1-2). The result indicated higher observed values compared to simulated values. The similar study conducted by Kumar et al. (2014) revealed that higher simmulated the days to anthesis than simulated in wheat ranged between 93 to 96 and 93 to 97 respectively using CERES-wheat under Uttara- 
Table 1. Impact of elevated $\mathrm{CO}_{2}$ (420 and $470 \mathrm{ppm}$ ) levels on of late sown wheat crop under limited irrigations.

\begin{tabular}{llllll}
\hline Planting window & \multicolumn{2}{c}{ Grain yield $(\mathbf{k g} / \mathbf{h a})$} & & \multicolumn{2}{c}{ Percent increase/decrease } \\
\cline { 2 - 5 } & $\mathbf{3 7 0} \mathbf{~ p p m}$ & $\mathbf{4 2 0} \mathbf{~ p p m}$ & $\mathbf{4 7 0} \mathbf{~ p m}$ & $\mathbf{5 0} \mathbf{~ p p m}$ & $\mathbf{1 0 0} \mathbf{~ p p m}$ \\
\hline $30^{\text {th }}$ November & 4307.1 & 4480.4 & 4381.5 & 4.0 & 1.7 \\
$15^{\text {th }}$ December & 3339.0 & 3468.8 & 3590.9 & 3.8 & 7.5 \\
$30^{\text {th }}$ December & 2103.5 & 2180.0 & 2244.5 & 3.6 & 6.7 \\
\hline
\end{tabular}

Table 2. Impact of elevated 1 and $2{ }^{\circ} \mathrm{C}$ rise in temperature on days to anthesis, maturity and grain yield of late sown wheat under limited irrigations.

\begin{tabular}{|c|c|c|c|c|c|c|c|c|c|}
\hline \multirow{2}{*}{$\begin{array}{l}\text { Planting } \\
\text { window }\end{array}$} & \multicolumn{3}{|c|}{ Days to anthesis } & \multicolumn{3}{|c|}{ Days to maturity } & \multicolumn{3}{|c|}{ Grain yield (kg/ha) } \\
\hline & $\begin{array}{l}\text { Control } \\
(370 \text { ppm) }\end{array}$ & $\mathbf{1}^{\circ} \mathrm{C}$ & $2^{\circ} \mathrm{C}$ & $\begin{array}{l}\text { Control } \\
(370 \text { ppm) }\end{array}$ & $1^{\circ} \mathrm{C}$ & $2^{\circ} \mathrm{C}$ & $\begin{array}{l}\text { Control } \\
(370 \text { ppm })\end{array}$ & $1^{\circ} \mathrm{C}$ & $2^{\circ} \mathrm{C}$ \\
\hline $30^{\text {th }}$ November & 137 & 131 & 126 & 165 & 160 & 157 & 4307.1 & $5078.8(17.9)$ & $5738.1(33.2)$ \\
\hline $15^{\text {th }}$ December & 126 & 119 & 115 & 151 & 147 & 144 & 3339.0 & $4759.5(42.5)$ & $4966.1(48.0)$ \\
\hline $30^{\text {th }}$ December & 116 & 111 & 105 & 139 & 135 & 132 & 2103.5 & $3428.6(63.0)$ & $4488.2(113.4)$ \\
\hline
\end{tabular}

*values in parenthesis are percent increase and decrease in yield

Table 3. Impact of elevated $\mathrm{CO}_{2}(50 \& 100 \mathrm{ppm})$ and 1 and $2{ }^{\circ} \mathrm{C}$ rise in temperature of late sown wheat crop on days to anthesis and maturity under limited irrigations.

\begin{tabular}{|c|c|c|c|c|c|c|c|c|c|c|}
\hline \multirow{3}{*}{$\begin{array}{l}\text { Planting } \\
\text { window }\end{array}$} & \multicolumn{5}{|c|}{ Days to anthesis } & \multicolumn{5}{|c|}{ Days to maturity } \\
\hline & \multirow[t]{2}{*}{$\begin{array}{l}\text { Control } \\
\text { (370 ppm) }\end{array}$} & \multicolumn{2}{|c|}{$\begin{array}{l}420 \text { ppm }(50 \\
\text { ppm) }\end{array}$} & \multicolumn{2}{|c|}{$\begin{array}{l}470 \text { ppm (100 } \\
\text { ppm) }\end{array}$} & \multirow[t]{2}{*}{$\begin{array}{l}\text { Control } \\
\text { (370 ppm) }\end{array}$} & \multicolumn{2}{|c|}{$\begin{array}{l}420 \mathrm{ppm} \\
(50 \mathrm{ppm})\end{array}$} & \multicolumn{2}{|c|}{$\begin{array}{l}470 \text { ppm (100 } \\
\text { ppm) }\end{array}$} \\
\hline & & $1^{\circ} \mathrm{C}$ & $2^{\circ} \mathrm{C}$ & $1^{\circ} \mathrm{C}$ & $2{ }^{\circ} \mathrm{C}$ & & $1^{\circ} \mathrm{C}$ & $2^{\circ} \mathrm{C}$ & $1^{\circ} \mathrm{C}$ & $2{ }^{\circ} \mathrm{C}$ \\
\hline $30^{\text {th }}$ November & 137 & 131 & 126 & 131 & 125 & 165 & 160 & 157 & 160 & 157 \\
\hline $15^{\text {th }}$ December & 126 & 119 & 115 & 119 & 115 & 151 & 147 & 144 & 147 & 144 \\
\hline $30^{\text {th }}$ December & 116 & 111 & 105 & 111 & 105 & 139 & 135 & 132 & 135 & 132 \\
\hline
\end{tabular}

Table 4. Impact of elevated $\mathrm{CO}_{2}(50 \& 100 \mathrm{ppm})$ and 1 and $2{ }^{\circ} \mathrm{C}$ rise in temperature of late sown wheat crop on grain yield and percent increase/decrease under limited irrigations.

\begin{tabular}{|c|c|c|c|c|c|c|c|c|c|}
\hline \multirow[t]{3}{*}{ Planting window } & \multicolumn{5}{|c|}{ Grain yield (kg/ha) } & \multicolumn{4}{|c|}{ Percent increase/decrease } \\
\hline & \multirow[t]{2}{*}{$\begin{array}{l}\text { Control } \\
(370 \text { ppm })\end{array}$} & \multicolumn{2}{|c|}{420 ppm (50 ppm) } & \multicolumn{2}{|c|}{470 ppm (100 ppm) } & \multicolumn{2}{|c|}{$\begin{array}{l}420 \mathrm{ppm} \\
(50 \mathrm{ppm})\end{array}$} & \multicolumn{2}{|c|}{$\begin{array}{l}470 \text { ppm (100 } \\
\text { ppm) }\end{array}$} \\
\hline & & $1^{\circ} \mathrm{C}$ & $2{ }^{\circ} \mathrm{C}$ & $1^{\circ} \mathrm{C}$ & $2^{\circ} \mathrm{C}$ & $1^{\circ} \mathrm{C}$ & $2{ }^{\circ} \mathrm{C}$ & $1^{\circ} \mathrm{C}$ & $2{ }^{\circ} \mathrm{C}$ \\
\hline $30^{\text {th }}$ November & 4307.1 & 5297.1 & 6012.0 & 5508.2 & 6309.4 & 23.0 & 39.5 & 27.9 & 46.4 \\
\hline $15^{\text {th }}$ December & 3339.0 & 4973.2 & 5202.1 & 5185.4 & 5431.0 & 48.0 & 55.8 & 55.2 & 62.6 \\
\hline $30^{\text {th }}$ December & 2103.5 & 3570.2 & 4700.8 & 3705.3 & 4901.8 & 69.7 & 123.5 & 76.1 & 133.0 \\
\hline
\end{tabular}

khand agro-climatic condition. The study at Palampur (Fig.2) reflected more simulated yield in comparison to observed except in $30^{\text {th }}$ November, $15^{\text {th }}$ December in 2000 and $30^{\text {th }}$ November in 2001 sown crop.

Impact of elevated $\mathrm{CO}_{2}$ on wheat yield under limited irrigated condition: The simulated grain yield with the elevated $\mathrm{CO}_{2}$ levels of 50 and 100 ppm was obtained to the tune of 3.6 to 4.0 percent at $50 \mathrm{ppm}$. The higher increase in yield was observed in $30^{\text {th }}$ November sown crop followed by $15^{\text {th }}$ and $30^{\text {th }}$ December. The higher $\mathrm{CO}_{2}$ level of $100 \mathrm{ppm}$ showed increase in yield to the tune of 1.7 to 7.5 percent and delayed sowing also increased the yield of crop (Table 1). Kour et al., (2013) also reported increase in simulated wheat yield up to 18.3 percent with elevated $\mathrm{CO}_{2}$ to $350 \mathrm{ppm}$ from the base value $330 \mathrm{ppm}$ in temperate condition.

Impact of elevated levels of temperature: The increase in temperature by 1 and $2{ }^{0} \mathrm{C}$ also simulated higher yield in all the planting windows. The temperature rise of 1 and $2{ }^{\circ} \mathrm{C}$ showed increase in the yield of late sown wheat crop to the tune 17.9 to 63.0 and 33.2 to 113.4 percent, respectively under all planting windows. The highest yield was observed in $30^{\text {th }}$ December sown crop followed by $15^{\text {th }}$ December and lowest in $30^{\text {th }}$ November respectively in both 1 and $2{ }^{\circ} \mathrm{C}$ rise in temperature. Mishra et al. (2015) observed in Anand region of Gujarat that the rise in maximum temperature by $5^{\circ} \mathrm{C}$ may cause reduction in wheat yield by 24 to 29 percent . In present study, $1^{0} \mathrm{C}$ rise in temperature advanced the anthesis 5-7 days, whereas $2^{\circ} \mathrm{C}$ advanced it by 11 days. The impact of elevated temperature affected the maturity also as it affects the anthesis. Furthermore, the $1^{0} \mathrm{C}$ rise in temperature advanced maturity 4-5 days where as $2^{0} \mathrm{C}$ advanced it by 7-8 days. It may be due to advances in days of anthesis (Table 2). Prasad et al. (2016) observed that rabi 2011-12 witnessed higher temperature during heading which reduced the wheat yield by 84.3 and 45.2 per cent in rainfed and irrigated conditions of Palampur (H.P), respectively as compared to rabi 2010-11.

Impact of elevated temperature and carbon dioxide levels: The yield of wheat crop increased with rise in 1 and $2{ }^{\circ} \mathrm{C}$ temperatures when coupled with the elevated 


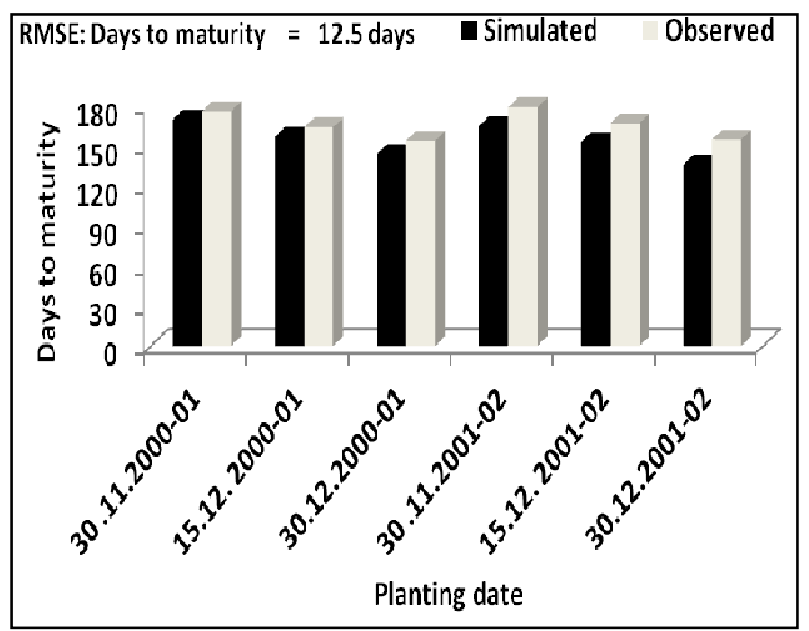

Fig. 1. Simulated and observed days to anthesis for rabi wheat crop in Palampur for late sown varieties.

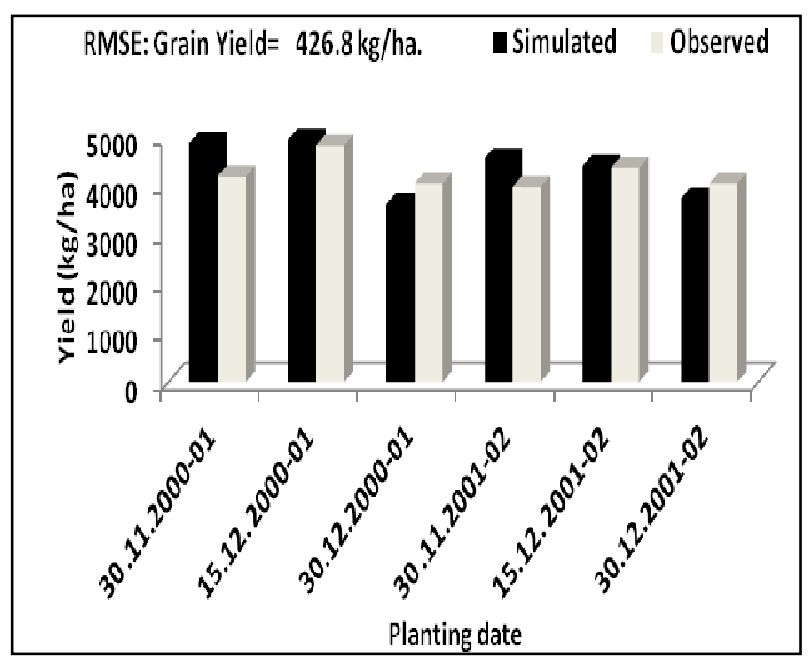

Fig. 2. Simulated and observed yield for rabi wheat crop in Palampur for late sown varieties.

$\mathrm{CO}_{2}$ levels of 50 and $100 \mathrm{ppm}$ in different dates of sowing i.e. 30 November, 15 and 30 December. The 1 and $2{ }^{\circ} \mathrm{C}$ elevated levels of temperature coupled with $50 \mathrm{ppm}$ level of $\mathrm{CO}_{2}$ increased the yield by 23.0 to 69.7 percent and 39.5 to 123.5 percent, respectively. The higher increase in yield obtained in $30^{\text {th }}$ December followed by the $15^{\text {th }}$ December and $30^{\text {th }}$ November, respectively as followed the same result of impact of elevated 1 and $2^{\circ} \mathrm{C}$ rise in temperature. Further increase of $100 \mathrm{ppm} \mathrm{CO}$ also increased the yield by the tune of 27.9 to 76.1 percent and 46.4 to 133.0 percent under 1 and $2{ }^{\circ} \mathrm{C}$ elevated levels of temperature, respectively. Similar results were obtained with $50 \mathrm{ppm}$ i.e. $30^{\text {th }}$ December late sown wheat yielded higher as compare to other date of sowings (Table 4) in Palampur region.

Furthermore, the effect of $1^{0} \mathrm{C}$ rise in temperature coupled with $50 \mathrm{ppm} \mathrm{CO}_{2}$ advanced the anthesis 5-7 days and maturity by $4-5$ days. Whereas $2{ }^{\circ} \mathrm{C}$ elevated temperature advanced 11 days and 7-8 days among days to anthesis and maturity respectively. When the elevated level $\mathrm{CO}_{2}$ (100) coupled with elevated temperature $\left(1 \& 2^{0} \mathrm{C}\right)$ resulted that with $1^{0} \mathrm{C}$ elevated temperature the advancement in anthesis was 5-7 days and maturity 4-5 days whereas, with elevated $2^{0} \mathrm{C}$ elevated temperature advancement was 11-12 days (anthesis) and 7-8 days (maturity) (Table 3). Yadav et al. (2015) revealed from the study conducted in Varanasi region that the productivity of rabi crop wheat decreased by 25.0 percent when temperature increased by $3.0{ }^{\circ} \mathrm{C}$ from normal at $330 \mathrm{ppm} \mathrm{CO}_{2}$ concentration.

\section{Conclusion}

The present study assessed that elevated levels of $\mathrm{CO}_{2}$ which resulted in increase in yield in late sown in all planting windows whereas higher yields were obtained in $30^{\text {th }}$ November at $50 \mathrm{ppm} \mathrm{CO}$ and $15^{\text {th }}$ December at $100 \mathrm{ppm} \mathrm{CO} 2$ i.e 4480.4 (4 percent) and $3590.9 \mathrm{~kg} / \mathrm{ha}$ (7.5 percent). The increase in temperature by $1^{\circ} \mathrm{C}$ and $2^{\circ} \mathrm{C}$ increased the yield in all the planting windows of late sown wheat to the tune of 17.9 to 63.0 percent and 33.2 to 113.4 percent, respectively whereas $30^{\text {th }}$ December proved to be the best planting window. The simulated yield of late sown wheat crop under irrigated conditions at Palampur increased with rise in $1^{\circ} \mathrm{C}$ and $2^{\circ} \mathrm{C}$ temperature when coupled with the elevated $\mathrm{CO}_{2}$ levels of 50 and $100 \mathrm{ppm}$ over different dates of sowing. The increase in the yield was found to be 23.0 to 69.7 percent and 39.5 to 123.5 percent under $1{ }^{\circ} \mathrm{C}$ and $2^{\circ} \mathrm{C}$ elevated temperature levels with elevated $\mathrm{CO}_{2}$ level to $50 \mathrm{ppm}$ and 27.9 to 76.1 percent and 46.4 to 133.0 percent under 1 and $2^{\circ} \mathrm{C}$ elevated temperature level with $100 \mathrm{ppm}$, respectively under limited irrigations. The 1 and $2{ }^{\circ} \mathrm{C}$ rise in temperature coupled with $50 \mathrm{ppm}$ and $100 \mathrm{ppm}$ higher level of $\mathrm{CO}_{2}$ advanced the maturity of the late sown wheat crop by 4 to 5 and 7 to 8 days, respectively. Amongst the different planting window $30^{\text {th }}$ December planting window proved to be yielded higher with rise in temperature alone and along with the elevated $\mathrm{CO}_{2}$ level (50 $\mathrm{ppm}$ and 100ppm) as compare to other planting dates $\left(30^{\text {th }}\right.$ November and $15^{\text {th }}$ December). Hence, the elevated levels of temperatures by 1 and $2^{\circ} \mathrm{C}$ and $\mathrm{CO}_{2}$ levels by 50 and $100 \mathrm{ppm}$ from $370 \mathrm{ppm}$ proved to be beneficial in rabi wheat with adaptations strategy of limited irrigations under sub temperate climate of North Western Himalayas.

\section{ACKNOWLEDGEMENTS}

Authors are thankful to National Coordinator, Network Project on Climate Change (NPCC), and ICAR for providing financial assistance to carry out the research work. Also thankful to CSKHPKV, Palampur for providing the necessary facilities for the study. 


\section{REFERENCES}

Aggarwal, P.K., Banerjee, B., Daryaei, M.G., Bhatia, A., Bala, A., Rani, S., Chander, S., Pathak, H. and Kalra, N. (2006a). InfoCrop: a dynamic simulation model for the assessment of crop yields, losses due to pests, and environmental impact of agro-ecosystems in tropical environments. I. Model description. Agri. Syst., 89: 1-25.

Aggarwal, P.K., Banerjee, B., Daryaei, M.G., Bhatia, A., Bala, A., Rani, S., Chander, S., Pathak, H. and Kalra, N. (2006b). InfoCrop: A dynamic simulation model for the assessment of crop yields, losses due to pests, and environmental impact of agro-ecosystems in tropical environments II. Performance of the model. Agri. Syst., 89: $47-67$.

Anonymous, (2015). Food and Agriculture Organization of the United Nations. http://FAOSTAT.fao.org

Anonymous . (2014) .Economic survey of Himachal Pradesh (2014-2015): pp 41-45

Bhagat, R.M., Rana, R.S., Prasad, R., Lal, H., Kalia, V. and Sood, C. (2007). Annual progress report of the project "Impact, Vulnerability and Adaptation of Mountain Agriculture to Climate Change" ICAR, New Delhi, India.

Kour, M., Singh K. N., Singh, M., Thakur, N. P., Kachroo, D. and Sharma, R. (2013). Assessment of climate change and its impact on growth and yield of wheat under temperate and sub-tropical conditions. Journal of Agrometeorology 15 (2) : 142-146
Kumar, Naresh S., Aggarwal, P.K., Swaroopa, Rani D.N.,Saxena, R., Chauhan, N., Jain, S. (2014). Vulnerability of wheat production to climate change in India.Climate Research; 59(173-187):5-187.

Mendelsohn, R. (2014). The impact of climate change on agriculture in Asia. J Integr Agric. ; 13(4):660-665.

Mishra, S.K., Shekh, A.M., V. Pandey, Yadav, S.B. and Patel, H.R. (2015). Sensitivity analysis of four wheat cultivars to varying photoperiod and temperature at different phonological stages using WOFOST model. Journal of Agrometeorology 17(1): 74-79.

Ortiz, R., Sayre, K.D., Govaerts, B., Gupta, R., Subbarao, G.V., Ban, T., Hodson, D., Dixon, J.M., Ortiz, M.J.I., Reynolds, M. (2008). Climate change: can wheat beat the heat? Agri. Eco. Env., 126 (1-2): 46-58.

Prasad, R., Kumar, S., Sehgal, S. and Sharma, A. (2016). Temperature effects on yield of wheat (Triticum aestivum L.) under mid hill conditions of Himachal Pradesh. Himachal Journal of Agricultural Research 42(1): 60-65

Richter, G.M. and Semenov, M. A. (2005). Modelling impacts of climate change on wheat yields in England and Wales: assessing drought risks. Agri. Syst., 84: 77-97.

Yadav, M.K., Singh, R.S., Singh, K.K., Mall, R.K., Patel, C.B., Yadav, S.K. and Singh, M.K. (2015). Assessment of climate change impacts on productivity of different cereal crops in Varanasi. Journal of Agrometeorology 17 (2): 179-184. 